\title{
The technique of using balls of different weights and diameters for the interrelated development of physical qualities, accuracy of strikes and psychophysiological capabilities of young football players
}

\author{
Kanishchev O.G. ${ }^{1}$, Kozina Zh.L. ${ }^{1}$, Grynyova V.M. ${ }^{2}$, Masych V.V. ${ }^{3}$ \\ ${ }^{1}$ Department of Olympic and Professional Sports, Sports Games and Tourism, H.S. Skovoroda \\ Kharkiv National Pedagogical University, Kharkiv, Ukraine \\ ${ }^{2}$ Department of Primary and Professional Education Department, H. S. Skovoroda Kharkiv National \\ Pedagogical University, Kharkiv, Ukraine \\ ${ }^{3}$ Department of Physics and Cyber Technical Systems, H. S. Skovoroda Kharkiv National \\ Pedagogical University, Kharkiv, Ukraine
}

DOI: https://doi.org/10.34142/HSR.2021.07.01.03

\section{How to Cite}

Kanishchev OG, Kozina ZhL, Grynyova VM, Masych VV. The technique of using balls of different weights and diameters for the interrelated development of physical qualities, accuracy of strikes and psychophysiological capabilities of young football players. Health, Sport, Rehabilitation. 2021;7(1):39-46. https://doi.org/10.34142/HSR.2021.07.01.02

\begin{abstract}
Purpose : determination of the influence of the technique of using balls of different weights and diameters on the level and structure of psychophysiological indicators, physical and technical fitness of football players at the initial stage of training.

Material and methods. The study was attended by 22 young footballers $10-12$ years old. The subjects were divided into two groups (control and experimental) for 11 people in each. The control and experimental group trained the same amount of time for the same progips, but in the experimental group, in the main part of the class, used the technique of complex development of precision-target movements. Measured the level of physical and technical preparedness, as well as the level of psychophysiological functions of athletes.

Results. It is shown that the experimental group experienced significant improvements in the techniques of football due to the development of precision-oriented skills. Really improved results of physical and technical preparedness of athletes of the experimental group were revealed. The control group is also characterized by a significant improvement in testing results by level of technical and physical fitness, but not reliable or at a lower level of significance. The positive influence of the method of complex development of precision-target movements on the psychophysiological indices of athletes is shown. It was shown that after the experiment, the number of reliable interrelationships between the indicators of psychophysiological functions and the indicators of technical and physical fitness in the experimental group increased, and in the control remained unchanged.

Conclusions. The application of the experimental methodology for the development of precision-target movements positively influenced the level of technical and physical preparedness, psycho-physiological indicators, as well as the structure of the complex preparedness of athletes.

Keywords: football, athlete, accuracy, strike, psycho-physiological indicators, technical readiness
\end{abstract}

(C) Kanishchev O.G., Kozina Zh.L., Grynyova V.M., 


\section{Анотація}

Каніщев О.Г., Козіна Ж.Л., Гриньова В.М., Масіч В.В. Методика застосування м'ячів різної ваги і діаметра для взаємопов'язаного розвитку фізичних якостей, точності ударів і психофізіологічних можливостей юних футболістів

Мета: визначення впливу методики застосування м'ячів різної ваги та різного діаметру на рівень та структуру психофізіологічних показників, фізичної та технічної підготовленості футболістів на початковому етапі підготовки. Матеріал і методи. У дослідженні прийняли участь 22 юних футболіста 10-12 років. Випробувані були розділені на дві групи (контрольну і експериментальну) по 11 осіб в кожній. Контрольна та експериментальна група тренувалися за однаковими прогпамами однакову кількість часу, але в експериментальній групі в основній частині заняття застосовувала методика комплексного розвитку точнісно-цільових рухів. Вимірювався рівень фізичної та технічної підготовленості, а також рівень психофізіологічних функцій спортсменів.

Результати. Показано, шо у випробуваних експериментальної групи достовірно поліпшились показники техніки футболу за рахунок розвитку точнісно-цільових навичок. Виявлено достовірне поліпшення результатів фізичної та технічної підготовленості спортсменів експермиентальної групи. Для контрольної групи також характерно достовірне поліпшення результатів тестування за рівнем технічної та фізичної підготовленості, але не достовірне або при меншому рівні значущості. Показано позитивний вплив застосування методики комплексного розвитку точнісно-цільових рухів на психофізіологічні показники спортсменів. Показано, що після проведення експерименту кількість достовірних взаємозв' язків між показниками психофізіологічних функцій та показниками технічної та фізичної підготовленості в експериментальній групі підвищилась, а в контрольній залишилась без змін.

Висновки. Застосування експериментальної методики розвитку точнісно-цільових рухів позитивно вплинуло на рівень технічної та фізичної підготовленості, психофізіологічні показники, а також на структуру комплексної підготовленості спортсменів.

Ключові слова: футбол, спортсмен, точність, удар, психофізіологічні показники, технічна підготовленість

\section{Аннотация}

Канищев А.Г., Козина Ж.Л., Гринева В.Н., Масич В.В. Методика применения мячей разного веса и диаметра для взаимосвязанного развития физических качеств, точности ударов и психофизиологических возможностей юных футболистов

Цель: определение влияния методики применения мячей разного веса и диаметра на уровень и структуру психофизиологических показателей, физической и технической подготовленности футболистов на начальном этапе подготовки.

Материал и методы. В исследовании приняли участие 22 юных футболиста 10-12 лет. Испытуемые были разделены на две группы (контрольную и экспериментальную) по 11 человек в каждой. Контрольная и экспериментальная группа тренировались по одинаковым прогпамамы одинаковое количество времени, но в экспериментальной группе в основной части занятия применяла методика комплексного развития точностныецелевых движений. Измерялся уровень физической и технической подготовленности, а также уровень психофизиологических функций спортсменов.

Результаты. Показано, шо у испытуемых экспериментальной группы достоверно улучшились показатели техники футбола за счет развития точностные-целевых навыков. Выявлено достоверное улучшение результатов физической и технической подготовленности спортсменов експермиентальнои группы. Для контрольной группы также характерно достоверное улучшение результатов тестирования по уровню технической и физической подготовленности, но не достоверное или при меньшем уровне значимости. Показано положительное влияние применения методики комплексного развития точностные-целевых движений на психофизиологические показатели спортсменов. Показано, что после проведения эксперимента количество достоверных взаимосвязей между показателями психофизиологических функций и показателями технической и физической подготовленности в экспериментальной группе повысилась, а в контрольной осталась без изменений.

Выводы. Применение экспериментальной методики развития точностные-целевых движений положительно повлияло на уровень технической и физической подготовленности, психофизиологические показатели, а также на структуру комплексной подготовленности спортсменов.

Ключевые слова: футбол, спортсмен, точность, удар, психофизиологические показатели, техническая подготовленность 


\section{Introduction}

At the present stage the question of complex role development of physical qualities in combination with development of accuracy of blows of young football players acquires great urgency. The development of target accuracy is an integral part of the development of the athlete in the development of physical qualities, technical training. Studies $[1,2]$ have shown that the target accuracy is a complex quality that requires the manifestation of both physical indicators and indicators of functional fitness, the development of psychophysiological functions and so on.

A study by Fiorilli, Mariano, Iuliano, Giombini, Ciccarelli, Buonsenso, Calcagno, di Cagno [3] showed the positive effect of a 6-week training program with isoinertial eccentric overload using an inertial device during certain football exercises on explosive and reactive strength, ability to sprint, change direction, performance and hitting accuracy. Thirty-four youth football players were randomly assigned to a plyometric training group $(\mathrm{PT})(\mathrm{n}=16$, age $13.36 \pm 0.80)$, which underwent a six-week traditional football training program, and an eccentric overload (FEO) group $(\mathrm{n}=16$, age $13.36 \pm 0.80) .=18$, age $13.21 \pm 1.21$ ) who underwent additional training, consisting of two sessions of inertial eccentric overload per week. Pre- and postintervention tests were conducted to assess explosive and reactive strength, sprint ability, punching ability, agility using the Agility Test (YT), and hitting accuracy in football. The inertial eccentric overload group showed significantly higher values than the plyometric training group in terms of the height of various jumps and hitting accuracy in football $(\mathrm{p}=$ $0.02-0.001)$, as well as in alcohol $(p=0.001)$. These results confirmed the beneficial effects of isoinertial training. Using an isoinertial device to overload multidirectional movements in certain sporting conditions results in greater performance gains than in conventional soccer training. The authors conclude that the lack of knowledge about the eccentric overload applied by the isoinertial device, which is different for any repetition of the exercise, can stimulate the athlete's neural adaptations, improving his football skills and, in particular, the accuracy of kicks in football.

The positive influence of the complex methodology for the development of physical qualities and accuracy of strikes among young football players is also shown in studies $[4,5,6]$. Peker, Böge, Bailey, Wagman, Stoffregen [4] showed that with an increase in the level of preparedness, the strength and accuracy of strikes in football increase.
Therefore, the authors propose to apply a comprehensive methodology for the development of physical qualities and accuracy of strikes.

Merlin, Cunha, Moura, Torres, Gonçalves, Sampaio [5] classified ball possession by duration and number of passes and determined which tactical actions most reflect differences in ball passing in football. The authors found that the accuracy and range of ball passing depends on the tactical interactions used by the players. Coito, Davids, Folgado, Bento, Travassos [6] in the literature review identified the most effective methods for assessing the tactical behavior of players. Patterns of tactical behavior were analyzed using approximate entropy, sample entropy, Shannon's entropy, and coordination patterns between players and teams were analyzed using the correlation between strike phase and running speed. It was found that the greatest effect is given by methods that determine the effectiveness of the tactical behavior of football players in conjunction with the complex manifestation of physical qualities, accuracy of actions and peculiarities of thinking.

Complex development of punches accuracy, strength, speed, endurance, agility is also effective for preventing injuries and diseases of football players [7-12], for increasing the functional capabilities of vegetative-vascular regulation [13]. The authors of [14] revealed the influence of body size on the effectiveness of the game of football players from different regions and showed that the accuracy of strikes in football is a complex psychomotor function that depends on the morphological characteristics of the players, which determines the development of physical qualities [15].

Latorre, Zuniga, Arriaza, Moya, Nikulin [16] showed that in collective sports, the methods of psychophysiological capabilities (reactive agility, speed of reaction) when modeling various game situations allow to evaluate and improve the player's results. This is due to the fact that it is possible to take into account the combination of technical, tactical, physical and psychological abilities, as in real game situations. The authors proposed a new technique for reactive agility development (neural learning). This technique focuses on accurately measuring two of the most important variables for training reactive agility: total reaction time and correct responses, associated with the sequence of stimuli presented to the player. The incentives have been designed to properly represent realistic competition conditions for training players in a football context. The paper shows the effectiveness of this methodology for improving the complex fitness of football players.

Thus, modern scientific research reveals the 
importance of forming the right technique in the precision-target movements of sportsmens [17-21]. But the question of developing special methods for developing accurate actions remains insufficiently disclosed. Exercises specific to a certain sport without special exercises for the development of target accuracy as a complex psychomotor quality are mainly used in training [2]. It is logical to conclude that the application of methods of development of physical qualities and accuracy will have a positive effect on the level of complex training of football players. As such a technique can be the use of balls of different sizes and weights to perform special exercises by young players. We anticipate that this technique will have a positive effect on the development of psychophysiological capabilities in connection with the creation of conditions for the activation of different parts of the brain with a constant shift of attention from one motor action aimed at developing accuracy, to another.

The aim: determination of the influence of the technique of using balls of different weights and diameters on the level and structure of psychophysiological indicators, physical and technical fitness of football players at the initial stage of training.

\section{Matherials and methods}

\section{Participants}

The study was attended by 22 young players 10-12 years old. All children and their parents have agreed to participate in the experiment. The research was conducted from 01.03.2018 to 01.07.2018 on the basis of "Arsenal" Youth Sports School. The subjects were divided into two groups (control and experimental) for 11 people in each. Distribution was made by accident.

The study was conducted in accordance with the requirements of the Helsinki Declaration Ethics.

\section{Procedure}

The control and experimental group trained the same amount of time (4 times a week for 2 hours each training session) for the same progapam, but in the experimental group in the main part of the class, the technique of complex development of precisiontarget movements was used. In the control group at that time exercises were applied with the use of mobile games without the special focus on the development of precision-target movements. In the beginning and at the end of the experiment, athletes were tested. By the beginning of the experiment, the groups did not differ significantly from each other (Table 1) according to psychophysiological indices (according to Horbova and Schulte tests), according to indicators of physical preparedness (bendingextension of hands in the emphasis of lying and squatting) and indicators of technical readiness (accuracy of hits at the gate, an exact coordination test, a description of the tests are given below).

Intervention program: the Methodology of complex development of precision-target movements

The technique with the use of special precision-purpose exercises was used in the experimental group. The experimental group was engaged in the standard program, but the time at the common practice was reduced, and in the training were included additional exercises, such as throwing basketball into the basket, throwing the tennis ball into the target with distances of 3-10 m, blows $\mathrm{m}$ ' Bags of different sizes and different weight with a foot to the target with distances of 5-12 m, juggling with legs and hands with balls of different sizes and different weights. Exercises were conducted using sequential and game techniques.

\section{The test for the accuracy of hits at the gate}

Strike a foot on a stationary ball from a distance of $8 \mathrm{~m}$ in the gate. The ball must cross the gate line in the air and descend by $10 \mathrm{~m}, 12$ beats $(6$ right, 6 left leg). Estimated number of hits.

\section{Precision Coordination Test}

The footballer is in the center of the field (distance $50 \mathrm{~m}$ from the goal line). By the signal, without touching hands, juggles (at least 5 times) the ball, moving forward. Before the first stop, the ball stops the foot and successively circles 5 racks (distance to the first rack - $4 \mathrm{~m}$, between the racks -7 $\mathrm{m})$. Having reached the last stand but does not reach the line of the penalty area, he takes a kick on the ball by the foot to the goal. The ball must intersect in the air through the gates between the racks and under the crossbar. Evaluated quality and time of exercise (2 attempts, rated best) (s).

Investigation of the level of attention in the method of Horbova "Red-black table" [2, 20].

Purpoce: Estimation of switching and distribution of attention. Can be used to survey people of all ages. 
The study is conducted using special tables, in which randomly located 25 red and 24 black numbers. The tester must first find the black numbers in ascending order, then the red numbers in descending order. Immediately after the first task, the numbers in the table are mixed, and the subject begins to perform the second task. It consists in alternating the search for black numbers in the growing and red in descending order.

\section{Data Processing.}

The time taken for each series and the error are taken into account. The time of execution of the second task is not equal to the time of execution of the first task, because part of the time goes to switching the attention and operational content of the just mentioned numbers. The difference between two time indices will be the time of switching attention (ERV) from one row of numbers to another. The less this difference, the less the number of errors, the better the switching attention. Types of errors: skipping a number, repeating one number twice, choosing the wrong color number.

After completion, the results of the first and second tests, as well as ERW are displayed on the screen and automatically entered in the database.

Research of mental performance according to the method of "Table Schulte" [2, 20]

\section{Purpose}

Determination of stability of attention and dynamics of efficiency. Used to survey people of all ages. The tested in turn offers five tables, on which randomly numbers are from 1 to 25 . The searcher looks for, shows and names the numbers in the order of their growth. The sample is repeated with five different tables.

The main indicator is the time of execution. According to the results of each table, a depletion curve (fatigue) can be constructed, which reflects the stability of attention and performance in dynamics.

With this test, you can also calculate indicators such as performance (EP), degree of exercise (BP), mental resistance (PU).

$$
\mathrm{ER}=\text {------- } 5
$$

where T1 - time of work with the first table; $\mathrm{T} 2$ - from the second; TK - from the third; T4 - from the fourth; T5 - from the fifth.

The degree of development (BP) is calculated by the formula:

$$
\mathrm{BP}=\frac{\mathrm{T} 1}{\mathrm{ER}}
$$

The result is less than 1,0 - the indicator of good training, respectively, the higher the given figure, the more the subject needs time to prepare for the main work. Mental endurance (endurance) is calculated by the formula:

$$
\mathrm{PU}=\mathrm{T4}
$$

Indicator of the result (PP) of less than 1,0 says good mental stability and, accordingly, the higher the given indicator, the worse the psychological stability of the researched before performing a given job. After completion, test results are automatically entered into the database.

\section{Statistical analysis}

The digital material obtained during the study was processed using traditional methods of mathematical statistics. For each indicator, the arithmetic mean value $X$, the mean square deviation $\mathrm{S}$ (standard deviation), and the validity of the differences between the parameters of the initial and final results, as well as between the control and experimental groups according to the $t$-student criterion with the corresponding level of significance (p) were determined.

A correlation analysis of the test parameters was also conducted for the experiment and after the experiment (the results of the control and experimental groups were processed separately for each group).

In mathematical treatment of the primary materials of this study, in addition to calculating primary statistics, a correlation analysis of the test indicators was conducted. Mathematical processing of data was carried out using Microsoft Excell's Data Analysis SPSS research programs. Differences were considered to be reliable at a significance level of $p$ $<0.05$.

\section{Results}

According to the results of the experiment, the control and experimental group did not differ significantly from each other $(\mathrm{p}<0.05)$ (Table 1$)$. 
Indicators of psychophysiological functions of physical and technical preparedness of young players of control and experimental groups for experiment

\begin{tabular}{|c|c|c|c|c|c|c|c|}
\hline \multirow{2}{*}{ Title of tests } & \multirow{2}{*}{ Group } & \multicolumn{6}{|c|}{ Statistical Indicators } \\
\hline & & $\mathrm{N}$ & $\bar{x}$ & $S$ & $\mathrm{~m}$ & $t$ & $p$ \\
\hline \multirow{2}{*}{$\begin{array}{l}\text { Methodology "Schulte Table, } \\
\text { Efficiency of Work", c.u. }\end{array}$} & $\mathrm{C}$ & 11 & 36.83 & 6.94 & 2.09 & -0.59 & 0.53 \\
\hline & $E$ & 11 & 38.40 & 5.69 & 1.72 & & \\
\hline \multirow{2}{*}{$\begin{array}{l}\text { Methodology «Table of Schulte, } \\
\text { speed of inclusion in work», c.u. }\end{array}$} & $\mathrm{C}$ & 11 & 1.05 & 0.04 & 0.01 & 0.17 & 0.86 \\
\hline & $\mathrm{E}$ & 11 & 1.04 & 0.04 & 0.01 & & \\
\hline \multirow{2}{*}{$\begin{array}{l}\text { Methodology "Schulte Table, } \\
\text { Mental Stability", c.u. }\end{array}$} & C & 11 & 1.08 & 0.17 & 0.05 & 0.56 & 0.55 \\
\hline & $E$ & 11 & 1.04 & 0.16 & 0.05 & & \\
\hline \multirow{2}{*}{$\begin{array}{l}\text { Methodology "Red-black table for } \\
\text { Gorbovym", mistakes when } \\
\text { working on the table number } 1\end{array}$} & $\mathrm{C}$ & 11 & 3.29 & 2.90 & 0.87 & -0.50 & 0.60 \\
\hline & $E$ & 11 & 3.95 & 2.88 & 0.87 & & \\
\hline \multirow{2}{*}{$\begin{array}{l}\text { Technique "Red-black table for } \\
\text { Gorbovym", ponilki at work on the } \\
\text { table number } 2\end{array}$} & C & 11 & 7.38 & 6.74 & 2.03 & -0.43 & 0.63 \\
\hline & $\mathrm{E}$ & 11 & 8.66 & 6.53 & 1.97 & & \\
\hline \multirow{2}{*}{$\begin{array}{l}\text { Methodology "Red-black table for } \\
\text { Gorbovym", switching attention, } \\
\text { c.u. }\end{array}$} & $\mathrm{C}$ & 11 & 69.95 & 11.39 & 15.49 & -0.46 & 0.62 \\
\hline & $E$ & 11 & 70.38 & 11.71 & 15.59 & & \\
\hline \multirow{2}{*}{$\begin{array}{l}\text { The test for the accuracy of hits at } \\
\text { the gate, the number }\end{array}$} & $\mathrm{C}$ & 11 & 5.34 & 1.49 & 0.96 & 2.56 & 0.03 \\
\hline & $\mathrm{E}$ & 11 & 5.21 & 1.13 & 0.15 & & \\
\hline \multirow[t]{2}{*}{ Precision Coordination Test, $\mathrm{s}$} & $\mathrm{C}$ & 11 & 12.39 & 3.43 & 1.84 & -3.23 & 0.007 \\
\hline & $\mathrm{E}$ & 11 & 12.45 & 4.37 & 1.43 & & \\
\hline \multirow{2}{*}{$\begin{array}{l}\text { Bending-extensions of hands in the } \\
\text { emphasis lying in } 1 \text { minute, the } \\
\text { number }\end{array}$} & $\mathrm{C}$ & 11 & 12.35 & 2.84 & 0.86 & 0.37 & 0.73 \\
\hline & $\mathrm{E}$ & 11 & 13.24 & 3.21 & 0.97 & & \\
\hline \multirow[t]{2}{*}{ Squat for 1 minute, quantity } & $\mathrm{C}$ & 11 & 30.02 & 11.97 & 3.61 & 0.92 & 0.32 \\
\hline & $\mathrm{E}$ & 11 & 31.21 & 8.95 & 2.70 & & \\
\hline
\end{tabular}

Note: $\mathrm{C}$ is a control group; $\mathrm{E}$ is an experimental group

The lack of significant differences between the control and the experimental group prior to the experiment gave rise to a pedagogical experiment.

Repeated testing in 4 months during which the experimental group used the method of integrated development of precision-target movements showed that there were significant differences between the control and experimental groups according to the technical readiness indicators ("Accuracy test for gate, quantity", $\mathrm{p}<0.05$ and "Precision Coordination Test, c", p <0.05) (Table 2).

Table 2

Indicators of psycho-physiological functions of physical and technical readiness of young football players of control and experimental groups after the experiment

\begin{tabular}{|c|c|c|c|c|c|c|c|}
\hline \multirow{2}{*}{ Title of tests } & \multirow{2}{*}{ Group } & \multicolumn{6}{|c|}{ Statistical Indicators } \\
\hline & & $\mathrm{N}$ & $\bar{x}$ & $\mathrm{~S}$ & $\mathrm{~m}$ & $\mathrm{t}$ & $\mathrm{p}$ \\
\hline \multirow{2}{*}{$\begin{array}{l}\text { Methodology "Schulte Table, } \\
\text { Efficiency of Work", c.u. }\end{array}$} & C & 11 & 34.88 & 7.65 & 2.31 & 0.35 & 0.02 \\
\hline & $\mathrm{E}$ & 11 & 25.48 & 5.27 & 1.19 & & \\
\hline \multirow{2}{*}{$\begin{array}{l}\text { Methodology «Table of Schulte, } \\
\text { speed of inclusion in work», c.u. }\end{array}$} & $\mathrm{C}$ & 11 & 1.04 & 0.06 & 0.02 & 0.41 & 0.68 \\
\hline & $\mathrm{E}$ & 11 & 1.03 & 0.05 & 0.01 & & \\
\hline \multirow{3}{*}{$\begin{array}{l}\text { Methodology "Schulte Table, } \\
\text { Mental Stability", c.u. }\end{array}$} & C & 11 & 1.08 & 0.15 & 0.05 & 1.09 & 0.29 \\
\hline & $E$ & 11 & 1.01 & 0.15 & 0.04 & & \\
\hline & C & 11 & 4.18 & 2.93 & 0.88 & 2.61 & 0.04 \\
\hline
\end{tabular}




\begin{tabular}{|c|c|c|c|c|c|c|c|}
\hline $\begin{array}{l}\text { Methodology "Red-black table for } \\
\text { Gorbovym", mistakes when } \\
\text { working on the table number } 1\end{array}$ & $\mathrm{E}$ & 11 & 1.09 & 2.66 & 0.80 & & \\
\hline \multirow{2}{*}{$\begin{array}{l}\text { Technique "Red-black table for } \\
\text { Gorbovym", ponilki at work on the } \\
\text { table number } 2\end{array}$} & C & 11 & 7.18 & 6.26 & 1.89 & -2.58 & 0.03 \\
\hline & $E$ & 11 & 4.82 & 2.95 & 0.10 & & \\
\hline \multirow{2}{*}{$\begin{array}{l}\text { Methodology "Red-black table for } \\
\text { Gorbovym", switching attention, } \\
\text { c.u. }\end{array}$} & C & 11 & 67.18 & 48.61 & 14.66 & -0.68 & 0.50 \\
\hline & $\mathrm{E}$ & 11 & 61.82 & 52.26 & 15.76 & & \\
\hline \multirow{2}{*}{$\begin{array}{l}\text { The test for the accuracy of hits at } \\
\text { the gate, the number }\end{array}$} & C & 11 & 6.73 & 1.79 & 0.35 & -2.76 & 0.02 \\
\hline & $\mathrm{E}$ & 11 & 8.45 & 1.68 & 0.92 & & \\
\hline \multirow{2}{*}{ Precision Coordination Test, s } & C & 11 & 12.33 & 3.79 & 0.35 & -2.54 & 0.02 \\
\hline & $\mathrm{E}$ & 11 & 11.75 & 3.68 & 1.92 & & \\
\hline \multirow{2}{*}{$\begin{array}{l}\text { Bending-extensions of hands in the } \\
\text { emphasis lying in } 1 \text { minute, the } \\
\text { number }\end{array}$} & C & 11 & 15.00 & 3.26 & 0.98 & -1.00 & 0.33 \\
\hline & $\mathrm{E}$ & 11 & 16.64 & 4.37 & 1.32 & & \\
\hline \multirow{2}{*}{ Squat for 1 minute, quantity } & C & 11 & 37.00 & 14.23 & 4.29 & 0.10 & 0.92 \\
\hline & $E$ & 11 & 36.45 & 11.40 & 3.44 & & \\
\hline
\end{tabular}

Note: $\mathrm{C}$ is a control group; $\mathrm{E}$ is an experimental group

Thus, the results of the test showed that the experimental group experienced a significant improvement in the technical readiness due to the development of precision-target skills.

In-group comparison on the test indicators showed a significant improvement in the results of physical and technical preparedness of athletes of the experimental group: "The test for the accuracy of hits at the gate", $p<0.01$; "Precision Coordination Test", $\mathrm{p}<0.01$; "Flexion-extensions of hands in the emphasis lying," $\mathrm{p}<0.01$; "Squatting", $\mathrm{p}<0,05$ (Table 3).

Table 3

Indicators of psychophysiological functions, physical and technical readiness of young football players of the experimental group before and after the experiment

\begin{tabular}{|c|c|c|c|c|c|c|c|}
\hline \multirow{2}{*}{ Title of tests } & \multirow{2}{*}{ Group } & \multicolumn{6}{|c|}{ Statistical Indicators } \\
\hline & & $\mathrm{N}$ & $\bar{x}$ & $\mathrm{~S}$ & $\mathrm{~m}$ & $\mathrm{t}$ & $\mathrm{p}$ \\
\hline \multirow{2}{*}{$\begin{array}{l}\text { Methodology "Schulte Table, } \\
\text { Efficiency of Work", c.u. }\end{array}$} & $\mathrm{BE}$ & 11 & 38.40 & 5.69 & 1.72 & 4.30 & 0.000 \\
\hline & $A E$ & 11 & 25.48 & 5.27 & 1.19 & & \\
\hline \multirow{2}{*}{$\begin{array}{l}\text { Methodology «Table of Schulte, } \\
\text { speed of inclusion in work», c.u. }\end{array}$} & $\mathrm{BE}$ & 11 & 1.02 & 0.04 & 0.01 & -0.61 & 0.550 \\
\hline & $\mathrm{AE}$ & 11 & 1.03 & 0.05 & 0.01 & & \\
\hline \multirow{2}{*}{$\begin{array}{l}\text { Methodology "Schulte Table, } \\
\text { Mental Stability", c.u. }\end{array}$} & $\mathrm{BE}$ & 11 & 1.02 & 0.16 & 0.05 & 0.16 & 0.876 \\
\hline & $\mathrm{AE}$ & 11 & 1.01 & 0.15 & 0.04 & & \\
\hline \multirow{2}{*}{$\begin{array}{l}\text { Methodology "Red-black table for } \\
\text { Gorbovym", mistakes when } \\
\text { working on the table number } 1\end{array}$} & $\mathrm{BE}$ & 11 & 3.95 & 2.88 & 0.87 & 3.69 & 0.002 \\
\hline & $A E$ & 11 & 1.09 & 2.66 & 0.80 & & \\
\hline \multirow{2}{*}{$\begin{array}{l}\text { Technique "Red-black table for } \\
\text { Gorbovym", ponilki at work on the } \\
\text { table number } 2\end{array}$} & BE & 11 & 8.66 & 6.53 & 1.97 & -0.06 & 0.000 \\
\hline & $A E$ & 11 & 4.82 & 2.95 & 0.10 & & \\
\hline \multirow{2}{*}{$\begin{array}{l}\text { Methodology "Red-black table for } \\
\text { Gorbovym", switching attention, } \\
\text { c.u. }\end{array}$} & $\mathrm{BE}$ & 11 & 80.36 & 51.71 & 15.59 & -0.07 & 0.948 \\
\hline & $\mathrm{AE}$ & 11 & 81.82 & 52.26 & 15.76 & & \\
\hline \multirow{2}{*}{$\begin{array}{l}\text { The test for the accuracy of hits at } \\
\text { the gate, the number }\end{array}$} & $\mathrm{BE}$ & 11 & 5.21 & 1.13 & 0.15 & -3.31 & 0.003 \\
\hline & $A E$ & 11 & 8.45 & 1.68 & 0.92 & & \\
\hline \multirow{3}{*}{ Precision Coordination Test, s } & $\mathrm{BE}$ & 11 & 12.45 & 4.37 & 1.43 & -3.48 & 0.002 \\
\hline & $\mathrm{AE}$ & 11 & 11.75 & 3.68 & 1.92 & & \\
\hline & BE & 11 & 13.24 & 3.21 & 0.97 & -3.51 & 0.002 \\
\hline
\end{tabular}




\begin{tabular}{lccccccc}
\hline \hline $\begin{array}{l}\text { Bending-extensions of hands in the } \\
\text { emphasis lying in } 1 \text { minute, the } \\
\text { number }\end{array}$ & $\mathrm{AE}$ & 11 & 16.64 & 4.37 & 1.32 & \\
\hline \multirow{2}{*}{ Squat for 1 minute, quantity } & $\mathrm{BE}$ & 11 & 31.21 & 8.95 & 2.70 & -2.73 & 0.013 \\
\cline { 2 - 8 } & $\mathrm{AE}$ & 11 & 36.45 & 11.40 & 3.44 & & \\
\hline
\end{tabular}

Note: $\mathrm{BE}$ - before the experiment; $\mathrm{AE}$ - after experiment

For the control group there is a tendency to improve the results of testing by the level of technical preparedness $(p>0,05)$, according to the level of physical preparedness, the difference is reliable at a lower level of significance at a lower level of significance: "bending-extension of the hands in the emphasis on lying, $\mathrm{p}<0.05$ (Table 4).

Table 4

Indicators of psychophysiological functions and technical preparedness of the young football players of the control group before and after the experiment

\begin{tabular}{|c|c|c|c|c|c|c|c|}
\hline \multirow{2}{*}{ Title of tests } & \multirow{2}{*}{ Group } & \multicolumn{6}{|c|}{ Statistical Indicators } \\
\hline & & $\mathrm{N}$ & $\bar{x}$ & $\mathrm{~S}$ & $\mathrm{~m}$ & $\mathrm{t}$ & $p$ \\
\hline \multirow{2}{*}{$\begin{array}{l}\text { Methodology "Schulte Table, } \\
\text { Efficiency of Work", c.u. }\end{array}$} & $\mathrm{BE}$ & 11 & 36.83 & 6.94 & 2.09 & 0.30 & 0.765 \\
\hline & $\mathrm{AE}$ & 11 & 34.88 & 7.65 & 2.31 & & \\
\hline \multirow{2}{*}{$\begin{array}{l}\text { Methodology «Table of Schulte, } \\
\text { speed of inclusion in work», c.u. }\end{array}$} & $\mathrm{BE}$ & 11 & 1.03 & 0.04 & 0.01 & -0.79 & 0.442 \\
\hline & $\mathrm{AE}$ & 11 & 1.04 & 0.06 & 0.02 & & \\
\hline \multirow{2}{*}{$\begin{array}{l}\text { Methodology "Schulte Table, } \\
\text { Mental Stability", c.u. }\end{array}$} & $\mathrm{BE}$ & 11 & 1.06 & 0.17 & 0.05 & -0.30 & 0.767 \\
\hline & $\mathrm{AE}$ & 11 & 1.08 & 0.15 & 0.05 & & \\
\hline \multirow{2}{*}{$\begin{array}{l}\text { Methodology "Red-black table for } \\
\text { Gorbovym", mistakes when } \\
\text { working on the table number } 1\end{array}$} & $\mathrm{BE}$ & 11 & 3.29 & 2.90 & 0.87 & -0.73 & 0.473 \\
\hline & $\mathrm{AE}$ & 11 & 4.18 & 2.93 & 0.88 & & \\
\hline \multirow{2}{*}{$\begin{array}{l}\text { Technique "Red-black table for } \\
\text { Gorbovym", ponilki at work on the } \\
\text { table number } 2\end{array}$} & $\mathrm{BE}$ & 11 & 7.18 & 6.26 & 1.89 & 0.07 & 0.948 \\
\hline & $\mathrm{AE}$ & 11 & 7.18 & 6.26 & 1.89 & & \\
\hline \multirow{2}{*}{$\begin{array}{l}\text { Methodology "Red-black table for } \\
\text { Gorbovym", switching attention, } \\
\text { c.u. }\end{array}$} & $\mathrm{BE}$ & 11 & 69.91 & 51.39 & 15.49 & 0.13 & 0.9 \\
\hline & $\mathrm{AE}$ & 11 & 67.18 & 48.61 & 14.66 & & \\
\hline \multirow{2}{*}{$\begin{array}{l}\text { The test for the accuracy of hits at } \\
\text { the gate, the number }\end{array}$} & $\mathrm{BE}$ & 11 & 5.34 & 1.49 & 0.96 & -1.35 & 0.29 \\
\hline & $A E$ & 11 & 6.73 & 1.79 & 0.35 & & \\
\hline \multirow{2}{*}{ Precision Coordination Test, s } & $\mathrm{BE}$ & 11 & 12.39 & 3.43 & 1.84 & -0.33 & 0.31 \\
\hline & $\mathrm{AE}$ & 11 & 12.33 & 3.79 & 0.35 & & \\
\hline \multirow{2}{*}{$\begin{array}{l}\text { Bending-extensions of hands in the } \\
\text { emphasis lying in } 1 \text { minute, the } \\
\text { number }\end{array}$} & $\mathrm{BE}$ & 11 & 12.35 & 2.84 & 0.86 & -2.79 & 0.011 \\
\hline & $\mathrm{AE}$ & 11 & 20.00 & 3.26 & 0.98 & & \\
\hline \multirow{2}{*}{ Squat for 1 minute, quantity } & $\mathrm{BE}$ & 11 & 30.02 & 11.97 & 3.61 & -1.43 & 0.169 \\
\hline & $\mathrm{AE}$ & 11 & 37.00 & 14.23 & 4.29 & & \\
\hline
\end{tabular}

Note: $\mathrm{BE}$ - before the experiment; $\mathrm{AE}$ - after experiment

Thus, in the experimental group, the improvement of the physical and technical readiness rates is more pronounced than in the control group.

It should be noted that the improvement in physiological function was observed in the experimental group in terms of "Table Schulte, efficiency» $(\mathrm{p}<0.001)$, «Red and black table by Gorbov errors when working on Table $1 »(\mathrm{p}<0.01)$, « Red-black table for Gorbovym ", errors in the work on the table 2" $(\mathrm{p}<0.001)$ (Table 3,4). This can be explained by the fact that psychophysiological indicators are characteristics of a complex manifestation of psychomotor functions. They reflect the harmonious functioning of the nervous system, which is also due to the general development of coordination abilities, one of the manifestations of which is precision accuracy.

To determine the performance of structured training, identify relationships between indicators of physiological function and performance of physical and technical preparedness correlation analysis was conducted performance testing of athletes control 
and experimental groups before and after the experiment (Table. 5-8). Prior to the experiment, the number of reliable relationships between psychophysiological indicators and indicators of

Correlation matrix of tests for young test group players before the experiment $(\mathrm{n}=22)$

\begin{tabular}{|c|c|c|c|c|c|c|c|c|c|c|}
\hline $\begin{array}{c}\text { Testing } \\
\text { Indicat } \\
\text { ors }\end{array}$ & 1 & 2 & 3 & 4 & 5 & 6 & 7 & 8 & 9 & 10 \\
\hline 1 & 1.00 & & & & & & & & & \\
\hline 2 & $0.55^{*}$ & 1.00 & & & & & & & & \\
\hline 3 & $-0.84^{*}$ & -0.09 & 1.00 & & & & & & & \\
\hline 4 & 0.13 & 0.34 & 0.07 & 1.00 & & & & & & \\
\hline 5 & -0.41 & 0.12 & 0.08 & 0.30 & 1.00 & & & & & \\
\hline 6 & -0.27 & 0.28 & 0.12 & $0.51^{*}$ & $0.97^{*}$ & 1.00 & & & & \\
\hline 7 & -0.16 & $-0.61^{*}$ & 0.11 & 0.00 & -0.32 & -0.38 & 1.00 & & & \\
\hline 8 & 0.18 & $-0.50^{*}$ & -0.45 & 0.08 & -0.12 & -0.15 & $0.62 *$ & 1.00 & & \\
\hline 9 & -0.29 & -0.40 & -0.24 & -0.35 & 0.29 & 0.04 & -0.18 & 0.08 & 1.00 & \\
\hline 10 & -0.03 & 0.04 & 0.07 & -0.21 & -0.21 & -0.28 & 0.41 & 0.42 & -0.16 & 1.00 \\
\hline
\end{tabular}

Notes:

1 - Methods "Schultte table, efficiency", c.u.

2 - Methods "Table Schulte, the speed of inclusion in the work", c.u.

3 - Methods "Schulte Table, Mental Stability", c.u.

4 - Technique "Red-black table for Gorbovym", cuttings at work on the table number 1

5 - Technique "Red-black table for Gorbovym", cuttings at work on the table number 2

6 - Methodology "Red-black table for Gorbovym", switching attention, c.u.

7 - The test for the accuracy of hits at the gate, the number

8 - Precision Coordination Test, $\mathrm{s}$

9 - Bending-extension of the hands in the emphasis lying in 1 minute, the number

10 - Squat for 1 minute, quantity

* - the correlation coefficients are reliable at $p<0.05$

Correlation matrix of testing young testers experimental group before the experiment $(\mathrm{n}=22)$

\begin{tabular}{|c|c|c|c|c|c|c|c|c|c|c|}
\hline $\begin{array}{l}\text { Testing } \\
\text { Indicat } \\
\text { ors }\end{array}$ & 1 & 2 & 3 & 4 & 5 & 6 & 7 & 8 & 9 & 10 \\
\hline 1 & 1.00 & & & & & & & & & \\
\hline 2 & 0.49 & 1.00 & & & & & & & & \\
\hline 3 & -0.72 & -0.02 & 1.00 & & & & & & & \\
\hline 4 & -0.28 & -0.41 & 0.45 & 1.00 & & & & & & \\
\hline 5 & -0.16 & -0.32 & 0.19 & 0.29 & 1.00 & & & & & \\
\hline 6 & -0.22 & -0.29 & 0.41 & $0.52^{*}$ & $0.93^{*}$ & 1.00 & & & & \\
\hline 7 & -0.12 & -0.17 & -0.16 & -0.35 & 0.38 & 0.31 & 1.00 & & & \\
\hline 8 & 0.15 & -0.02 & -0.17 & -0.39 & 0.42 & 0.42 & $0.94^{*}$ & 1.00 & & \\
\hline 9 & -0.19 & -0.08 & -0.09 & 0.11 & 0.18 & 0.06 & 0.32 & 0.11 & 1.00 & \\
\hline 10 & -0.18 & -0.11 & 0.25 & 0.21 & -0.28 & -0.27 & -0.16 & -0.28 & 0.43 & 1.00 \\
\hline
\end{tabular}


4 - Technique "Red-black table for Gorbovym", cuttings at work on the table number 1

5 - Technique "Red-black table for Gorbovym", cuttings at work on the table number 2

6 - Methodology "Red-black table for Gorbovym", switching attention, c.u.

7 - The test for the accuracy of hits at the gate, the number

8 - Precision Coordination Test, $\mathrm{s}$

9 - Bending-extension of the hands in the emphasis lying in 1 minute, the number

10 - Squat for 1 minute, quantity

* - the correlation coefficients are reliable at $p<0.05$

After the experiment, the number of reliable interconnections between the indicators of psychophysiological functions and the indicators of technical and physical fitness in the experimental group increased to 10 (Table 7). In the control group, the number of reliable interrelations between these indicators remained at the experimental level (5 interrelationships) (Table 8).

Table 7

Correlation matrix of the testing of young players of the experimental group after the experiment $(\mathrm{n}=11)$

\begin{tabular}{|c|c|c|c|c|c|c|c|c|c|c|}
\hline $\begin{array}{c}\text { Testing } \\
\text { Indicators }\end{array}$ & 1 & 2 & 3 & 4 & 5 & 6 & 7 & 8 & 9 & 10 \\
\hline 1 & 1.00 & & & & & & & & & \\
\hline 2 & 0.02 & 1.00 & & & & & & & & \\
\hline 3 & 0.25 & -0.34 & 1.00 & & & & & & & \\
\hline 4 & -0.36 & -0.49 & 0.12 & 1.00 & & & & & & \\
\hline 5 & -0.16 & 0.24 & 0.15 & 0.19 & 1.00 & & & & & \\
\hline 6 & -0.19 & 0.21 & 0.27 & 0.37 & 0.95 & 1.00 & & & & \\
\hline 7 & -0.21 & 0.35 & -0.22 & -0.35 & 0.12 & -0.23 & 1.00 & & & \\
\hline 8 & -0.12 & 0.53* & -0.15 & $-0.50 *$ & 0.23 & -0.26 & 0.94* & 1.00 & & \\
\hline 9 & $-0.67^{*}$ & -0.24 & -0.07 & 0.11 & $0.58 *$ & 0.57 & 0.43 & 0.17 & 1.00 & \\
\hline 10 & -0.31 & $-0.59 *$ & 0.16 & $0.52 *$ & $0.64^{*}$ & $0.69 *$ & -0.23 & -0.27 & $0.67 *$ & 1.00 \\
\hline
\end{tabular}

Notes:

1 - Methods "Schultte table, efficiency", c.u.

2 - Methods "Table Schulte, the speed of inclusion in the work", c.u.

3 - Methods "Schulte Table, Mental Stability", c.u.

4 - Technique "Red-black table for Gorbovym", cuttings at work on the table number 1

5 - Technique "Red-black table for Gorbovym", cuttings at work on the table number 2

6 - Methodology "Red-black table for Gorbovym", switching attention, c.u.

7 - The test for the accuracy of hits at the gate, the number

8 - Precision Coordination Test, $\mathrm{s}$

9 - Bending-extension of the hands in the emphasis lying in 1 minute, the number

10 - Squat for 1 minute, quantity

* - the correlation coefficients are reliable at $p<0.05$

Correlation matrix of tests for young testers of the control group after the experiment $(\mathrm{n}=11)$

\begin{tabular}{|c|c|c|c|c|c|c|c|c|c|c|}
\hline $\begin{array}{c}\text { Testing } \\
\text { Indicat } \\
\text { ors }\end{array}$ & 1 & 2 & 3 & 4 & 5 & 6 & 7 & 8 & 9 & 10 \\
\hline 1 & 1.00 & & & & & & & & & \\
\hline 2 & -0.14 & 1.00 & & & & & & & & \\
\hline 3 & -0.42 & -0.37 & 1.00 & & & & & & & \\
\hline 4 & 0.13 & 0.28 & 0.16 & 1.00 & & & & & & \\
\hline 5 & -0.43 & -0.39 & 0.72 & 0.38 & 1.00 & & & & & \\
\hline 6 & -0.392 & -0.12 & 0.75 & 0.65 & 0.93 & 1.00 & & & & \\
\hline 7 & 0.17 & -0.49 & 0.16 & -0.27 & 0.12 & -0.14 & 1.00 & & & \\
\hline
\end{tabular}


1 - Methods "Schultte table, efficiency", c.u.

2 - Methods "Table Schulte, the speed of inclusion in the work", c.u.

3 - Methods "Schulte Table, Mental Stability", c.u.

4 - Technique "Red-black table for Gorbovym", cuttings at work on the table number 1

5 - Technique "Red-black table for Gorbovym", cuttings at work on the table number 2

6 - Methodology "Red-black table for Gorbovym", switching attention, c.u.

7 - The test for the accuracy of hits at the gate, the number

8 - Precision Coordination Test, $\mathrm{s}$

9 - Bending-extension of the hands in the emphasis lying in 1 minute, the number

10 - Squat for 1 minute, quantity

* - the correlation coefficients are reliable at $p<0.05$

\section{Discussion}

The obtained data show that in the experimental group the harmony of the functioning of the nervous system from the point of view of motion management has increased, as the number of correlation relationships between the psychophysiological indicators and the level of physical and technical preparedness of the athletes has increased. This confirms the results we have received earlier that when the athlete's level of fitness increases, the level of self-organization of the system increases, which is an athlete or team [2]. These results confirm the theory of systems that are selforganizing to increase their structuring as they evolve [2]. The level of structuring of the system reflects the coherence of the work of its various systems, which indirectly reflects the existence of correlation relationships between different indicators of preparedness and work of different systems of the organism.

The obtained data also confirm the results of research on the development of precision-target movements in other sports [17]. The results obtained in previous studies [2] showed that target precision is a complex quality that depends on many factors and the work of different body systems. Precision-target precision is manifested comprehensively, that is, the development of precision-target movements in one kind of activity accelerates the development of precision-target movements in another type of activity. That is why the use of special precisiontarget exercises proposed in our experiment as additional means for the development of accuracy of archers has allowed to significantly affect the target performance of athletes. The obtained data confirm and extend the results on the effectiveness of the integrated development of target accuracy. But in football, such studies have not yet been conducted, and therefore the results are new in terms of improving the method of developing the target accuracy of young players at the initial stage of training.

In addition, the findings confirmed the results of authors' research on the importance of physical fitness for the implementation of precise actions. In the experimental group, the increase in physical fitness indicators is more pronounced than in the control group. This is also confirmed by the results of other authors' research [19-21] on the importance of physical fitness for the formation of sports movement techniques.

\section{Conclusion}

1. The application of the experimental methodology for the development of precision-target movements positively influenced the level of technical and physical preparedness, as well as the structure of the complex preparedness of athletes.

2. It is shown that the experimental group experienced significant improvements in the technique of football due to the development of precision-oriented skills. Really improved results of physical and technical preparedness of athletes of the experimental group: "The test for accuracy of hits at the gate, quantity", $\mathrm{p}<0.01$; "Precision Coordination Test, $c$ ", $p<0.01$; "Bending-extension of the hands in the emphasis lying," $p<0.01$; «Squatting», $p<0.05$. The control group is also characterized by a significant improvement in testing results by level of technical and physical fitness, but not reliable or at a lower level of significance. The existence of significant differences between the control and experimental groups according to the indicators of technical preparedness and psychophysiological indices was revealed $(\mathrm{p}<0.05)$.

The positive influence of the method of complex development of precision-target 
movements on the psychophysiological indices of athletes is shown. There was an agreement improvement of the psycho-physiological functions in the experimental group according to the indicators of Schulte's table, the efficiency of work ( $p<0.001$ ), the red-black table for Gorbovym, the errors when working on Table 1 "( $<<0.01)$," red-black table for Gorbovym ", errors at work on table 2" ( $\mathrm{p}<0.001)$.

3. It was shown that after the experiment, the number of reliable relationships between the indicators of psychophysiological functions and the indicators of technical and physical preparedness in the experimental group increased from 5 to 10 . In the control group, the number of reliable interrelations between these indicators remained at the preexperimental level (5 interconnections).

\section{Acknowledgments}

The study was conducted according to: research work, which is funded by the state budget of the Ministry of Education and Science of Ukraine for 2017-2018: "Theoretical and methodological foundations of the application of integrated technologies for self-improvement, harmonious physical, intellectual and spiritual development and the formation of a healthy lifestyle for people of different age and social groups, including athletes and people with special needs" (State Registration No: 0119U100616).

\section{Conflict of interest}

The authors declare that there is no conflict of interest.

\section{References}

1. Adi-Prasetya Bintang, Doewes Muchsin, Riyadi Slamet. Differences influence of drill, small sided games, and combination methods of two method skills on football players on beginners. Health, sport, $\begin{array}{llll}\text { rehabilitation, } & 2020 ; & 6(2): & 9-19 .\end{array}$ doi:10.34142/HSR.2020.06.02.01

2. Kozina ZhL, Seryi AV, Grinchenko IB, Bocharov K, Kuryat A, Glyadya SA, Vasilyev YuK, Ahmad M Ayaz. Method of complex development of psychomotor qualities in precisely-targeted sports. Health, sport, rehabilitation, 2018; 4(3): 7990. doi:10.34142/zenodo.1468170

3. Fiorilli G, Mariano I, Iuliano E, Giombini A, Ciccarelli A, Buonsenso A, Calcagno G, di Cagno A. Isoinertial Eccentric-Overload Training in Young Soccer Players: Effects on Strength, Sprint, Change of Direction, Agility and Soccer Shooting Precision. J Sports Sci Med. 2020;19(1):213-223.

4. Peker AT, Böge V, Bailey G, Wagman JB, Stoffregen TA. Perception of Affordances in Soccer: Kicking for Power Versus Kicking for Precision. Res Q Exerc Sport. 2020:1-9. doi: 10.1080/02701367.2020.1812494. Online ahead of print. PMID: 32924810

5. Merlin M, Cunha SA, Moura FA, Torres RDS, Gonçalves B, Sampaio J. Exploring the determinants of success in different clusters of ball possession sequences in soccer. Res Sports Med. 2020;28(3):339-350.

doi: 10.1080/15438627.2020.1716228. PMID: 31973582

6. Coito N, Davids K, Folgado H, Bento T, Travassos B. Capturing and Quantifying Tactical Behaviors in Small-Sided and Conditioned Games in Soccer: A Systematic Review. Res Q Exerc Sport. 2020;8:1-15. doi: 10.1080/02701367.2020.1823307. PMID: 33030987
7. Crossley KM, Patterson BE, Culvenor AG, Bruder AM, Mosler AB, Mentiplay BF. Making football safer for women: a systematic review and metaanalysis of injury prevention programmes in 11773 female football (soccer) players. Br J Sports Med. 2020;54(18):1089-1098. doi: 10.1136/bjsports2019-101587. PMID: 32253193

8. Grassi A, Macchiarola L, Filippini M, Lucidi GA, Della Villa F, Zaffagnini S. Epidemiology of Anterior Cruciate Ligament Injury in Italian First Division Soccer Players. Sports Health. 2020;12(3):279-288. doi: 10.1177/1941738119885642. PMID: 31800358

9. Raya-González J, Castillo D, Domínguez-Díez M, Hernández-Davó JL. Eccentric-Overload Production During the Flywheel Squat Exercise in Young Soccer Players: Implications for Injury Prevention. Int $\mathbf{J}$ Environ Res Public Health. 2020;17(10):3671. doi: 10.3390/ijerph17103671. PMID: 32456098

10. Beaudouin F, Gioftsidou A, Larsen MN, Lemmink K, Drust B, Modena R, Espinola JR, Meiu M, Vouillamoz M, Meyer T. The UEFA Heading Study: Heading incidence in children's and youth' football (soccer) in eight European countries. Scand J Med Sci Sports. 2020;30(8):1506-1517. doi: 10.1111/sms.13694. PMID: 32335945

11. Nuccio S, Del Vecchio A, Casolo A, Labanca L, Rocchi JE, Felici F, Macaluso A, Mariani PP, Falla D, Farina D, Sbriccoli P. Muscle fiber conduction velocity in the vastus lateralis and medialis muscles of soccer players after ACL reconstruction. Scand J Med Sci Sports. 2020 Oct;30(10):1976-1984. doi: 10.1111/sms.13748. PMID: 32516856

12. Pedrazzini A, Visigalli A, Valenti P, Bertoni N, Yewo Simo H, Bisaschi R, Medina V, Pedrabissi B, Ceccarelli F, Pogliacomi F. Medial epicondyle avulsion after elbow dislocation in an adolescent non-professional soccer player treated with a 
cannulated screw: a case report. Acta Biomed. 2020;91(4-S):271-275. doi: 10.23750/abm.v91i4S.9578. PMID: 32555109

13. Colosio AL, Lievens M, Pogliaghi S, Bourgois JG, Boone J. Heart rate-index estimates aerobic metabolism in professional soccer players. J Sci Med Sport. 2020;23(12):1208-1214. doi: 10.1016/j.jsams.2020.04.015. PMID: 32423737

14. Knudsen NS, Andersen TB. Morphology of possible regions in elite soccer players. Sports Biomech. 2020:1-14. doi: 10.1080/14763141.2020.1797862. Online ahead of print. PMID: 32935633

15. Rommers N, RÖssler R, Verhagen E, Vandecasteele F, Verstockt S, Vaeyens R, Lenoir M, D'Hondt E, Witvrouw E. A Machine Learning Approach to Assess Injury Risk in Elite Youth Football Players. Med Sci Sports Exerc. 2020;52(8):1745-1751. doi: 10.1249/MSS.0000000000002305. PMID: 32079917

16. Latorre EC, Zuniga MD, Arriaza E, Moya F, Nikulin C. Automatic Registration of Footsteps in Contact Regions for Reactive Agility Training in Sports. Sensors (Basel). 2020 Mar 19;20(6):1709. doi: 10.3390/s20061709. PMID: 32204336

17. Hart NH, Cochrane J L, Spiteri, T, Nimphius S, \& Newton RU. Relationship between Leg Mass, Leg Composition and Foot Velocity on Kicking Accuracy in Australian Football. Journal of Sports Science and Medicine, 2016;15(2): 344-351.
18. Hadlow SM, Pinder RA, Sayers MGL.Influence of football size on kicking performance in youth Australian rules footballers. Journal of Sports Sciences. 2017;35(18):1808-1816 doi:10.1080/02640414.2016.1239023

19. Grygorowicz M, Michalowska M, Walczak T, Owen A, Grabski J K, Pyda A, . . . Kotwicki, T. Discussion about different cut-off values of conventional hamstring-to-quadriceps ratio used in hamstring injury prediction among professional male football players. Plos One, 2017;12(12). doi:10.1371/journal.pone.0188974

20. Iermakov SS, Kozina ZL, Ceslitska M, Mushketa R. Razrabotka kompyuternyih programm dlya opredeleniya psihofiziologicheskih vozmozhnostey i svoystv nervnoy sistemyi lyudey s raznyim urovnem fizicheskoy aktivnosti [Computer program development for determination of psychophysiological possibilities and properties of thenervous system of people with the different level of physicalactivity]. Zdorov'â, sport, reabilitaciâ [Health, sport, rehabilitation], 2016; 2(1): 14-18.

21. Kozina Z, Iermakov S, Bartík P, Yermakova T, Michal J. Influence of self-regulation psychological and physical means on aged people's functional state. Journal of Human Sport and Exercise.2018;13(1):99-115. https://doi.org/10.14198/jh se.2018.131.10

Kanishchev O.G.

Information about the authors

zhanneta.kozina@gmail.com

H.S. Skovoroda Kharkiv National Pedagogical University

Alchevskih str. 29, Kharkov, 61002, Ukraine

\section{Kozina Zh. L.}

http://orcid.org/0000-0001-55884825

zhanneta.kozina@gmail.com

H.S. Skovoroda Kharkiv National Pedagogical University Altshevskih str. 29, Kharkiv, 61002, Ukraine

\section{Grynyova V.M.}

http://orcid.org/0000-0002-3027-4622

kvn.grineva@gmail.com

H.S. Skovoroda Kharkiv National Pedagogical University Altshevskih str. 29, Kharkiv, 61002, Ukraine

\section{Masych V.V.}

http://orcid.org/0000-0002-8943-7756

masych@hnpu.edu.ua

H.S. Skovoroda Kharkiv National Pedagogical University Altshevskih str. 29, Kharkiv, 61002, Ukraine 


\section{Інформація про авторів}

\section{Канішев О.Г.}

zhanneta.kozina@gmail.com

Харківський національний педагогічний університет

вул. Алчевських, 29, г. Харьков, 61002, Україна

\section{Козіна Ж.Л.}

http://orcid.org/0000-0001-5588-4825

zhanneta.kozina@gmail.com

Харківський національний педагогічний університет імені Г.С. Сковороди; вул.Алчевських 29, Харків, 61002, Україна

\section{Гриньова В.М.}

http://orcid.org/0000-0002-3027-4622

kvn.grineva@gmail.com

Харківський національний педагогічний університет імені Г.С. Сковороди; вул. Алчевських 29, Харків, 61002, Україна

\section{Масіч B.B.}

http://orcid.org/0000-0002-8943-7756

masych@hnpu.edu.ua

Харківський національний педагогічний університет імені Г.С. Сковороди; вул. Алчевських 29, Харків, 61002, Україна

\section{Информация об авторах}

\section{Канищев А.Г.}

zhanneta.kozina@gmail.com

Харьковский национальный педагогический университет

ул. Алчевских, 29, г. Харьков, 61002, Украина

\section{Козина Ж.Л.}

http://orcid.org/0000-0001-5588-4825

zhanneta.kozina@gmail.com

Харьковский национальный педагогический университет имени Г.С. Сковороды; ул.Алчевских 29, Харьков, 61002, Украина.

\section{Гринева В.Н.}

http://orcid.org/0000-0002-3027-4622

kvn.grineva@gmail.com

Харьковский национальный педагогический университет имени Г.С. Сковороды; ул.Алчевских 29, Харьков, 61002, Украина

\section{Масич В.В.}

http://orcid.org/0000-0002-8943-7756

masych@hnpu.edu.ua

Харьковский национальный педагогический университет имени Г.С. Сковороды; ул.Алчевских 29, Харьков, 61002, Украина

This work is licensed under a Creative Commons Attribution 4.0 International License (CC BY 4.0)

Received: 2020-12-15 Accepted: 2021-01-10 Published: 2021-03-20 